\title{
Technology as a tool in teaching quantitative biology at the secondary and undergraduate levels: a review
}

\author{
Miranda M. Chen ${ }^{a}$ (D), S. M. Scott ${ }^{a}$ and Jessica D. Stevens ${ }^{b}$ \\ ${ }^{a}$ Department of Ecology and Evolutionary Biology, University of Tennessee, Knoxville, TN, USA; ${ }^{b}$ Department \\ of Biosystems Engineering and Soil Science, University of Tennessee, Knoxville, TN, USA
}

\begin{abstract}
Since the publication of the National Research Council's Report BIO2010, efforts have increased to better integrate mathematics and biology in undergraduate education. Unfortunately, equivalent efforts to introduce these quantitative topics at the secondary level have been seldom. This could cause differential success of undergraduate students who come from diverse secondary science backgrounds. Undergraduate courses regularly use technology to integrate these two disciplines, and we believe that technology can similarly be used at the secondary level to prevent quantitative achievement mismatch in undergraduate biology programmes. In this paper, we review the current uses of technology to teach quantitative biology at the secondary and undergraduate levels, propose needs for further implementation, and address potential barriers to integrating mathematics and biology using technology.
\end{abstract}

\section{ARTICLE HISTORY}

Received 23 August 2017

Accepted 24 November

2017

\section{KEYWORDS}

Technology; quantitative biology; online resources; secondary education; undergraduate education

\section{Introduction}

In an exceedingly data-driven world, biologists face mounting pressure to be experienced in quantitative methods to analyse and synthesize biological processes (Feser, Vasaly, \& Herrera, 2013). Quantitative literacy is not only important for students majoring in biology and pursuing future careers in the field, it is also important that non-majors gain quantitative literacy to improve their ability to understand and interpret scientific findings (Gross, 2000; Handelsman et al., 2004; Waldrop et al., 2015). Quantitative biology needs to be introduced to students early in their educational pursuits to ensure their abilities are fully developed once they enter the workforce (Bialek \& Botstein, 2004). In 2003, the National Research Council (NRC) introduced BIO2010, which urged undergraduate biology programmes to increase the quantitative aspects of curricula (National Research Council, 2003). Many research and teaching intensive undergraduate institutions have implemented new degree programmes, courses, and research opportunities to satisfy this initiative (Aikens \& Dolan, 2014; Chapman, Christmann, \& Thatcher, 2006; Jungck, 2011; Jungck, Gaff, Fagen, \& Labov, 2010; Karsai \& Knisley, 2009; Lee \& Tsai, 2013; 
Table 1. Important terminology that will be used in this manuscript.

\begin{tabular}{ll}
\hline Term & \multicolumn{1}{c}{ Definition } \\
\hline $\begin{array}{l}\text { Activity } \\
\text { Module }\end{array}$ A single lesson or assignment \\
Composed of multiple activities or lectures; a series \\
Research, development, or application of computational tools and \\
approaches for expanding the use of biological, medical, behavioral, or \\
health data, including those to acquire, store, organize, archive, analyze, or \\
visualize such data (Cummings and Temple, 2010) \\
The development and application of data, analytical and theoretical \\
methods, mathematical modeling, and computational simulation \\
momputational biology & $\begin{array}{l}\text { techniques to the study of biological, behavioral, and social systems } \\
\text { (Cummings and Temple, 2010) } \\
\text { Aims to describe the different aspects of the real world, their interaction, } \\
\text { and their dynamics through mathematics (Quarteroni, 2009) }\end{array}$ \\
Quantitative biology & Includes bioinformatics, computational biology, and mathematical \\
& modeling (Cummings and Temple, 2010) \\
\hline
\end{tabular}

Marsteller et al., 2010; Robeva \& Laubenbacher, 2009; Waldrop et al., 2015). In this paper, we review examples in secondary and undergraduate courses that demonstrate how the use of technology can be an effective medium in which quantitative skills can be developed in a biology classroom (Balter, Enstrom, \& Klingenberg, 2013; Hennessy et al., 2007; Schroeder, Scott, Tolson, Huang, \& Lee, 2007) (Table 1).

The goals for learning quantitative biology (as stated in the NRC) focus on specific skills that students are expected to have by the end of their undergraduate studies (National Research Council, 2003). Aikens and Dolan (2014) believe that alongside this measurable skill-set there are ways to accompany development of understanding with more positive attitudes and motivation toward quantitative biology (Table 2). For example, studies have shown that using computer-based software, manipulative models, and other aspects of technology can help improve attitudes towards mathematics (Chiel, McManus, \& Shaw, 2010; Colon-Berlingeri and Burrowes, 2011; Jungck et al., 2010; Soderberg \& Price, 2003; Thompson, Nelson, Marbach-Ad, Keller, \& Fagan, 2010).

At the secondary education level, there exists no overarching initiative to include quantitative methods in all biology courses. The AP Biology framework is an exception to this rule, with more recent versions of the test stressing quantitative methods and synthesis of data, many of which are better taught using both lab and computational technologies (Jungck et al., 2010; The College Board, 2015). Though use of technology is not explicitly mentioned as a means for students to achieve these skills, they reference the use of many technological resources (e.g. BioQuest, MathBench) for teachers. Common Core Standards for mathematics also encourage the use of quantitative methods in creating and interpreting scientific experiments (Mayes \& Koballa, 2012). Outside of Common Core and AP Biology, however, other programs such as charter schools, prep schools, and homeschools have no explicit requirement to include quantitative methods in their biology curricula (Roberts, 2011). The inconsistency between secondary education programmes regarding development of quantitative biology skills results in early undergraduate students with differing levels of preparedness (Bialek \& Botstein, 2004; Gula, Hoessler, \& Maciejewski, 2015; Haak, HilleRisLambers, Pitre, \& Freeman, 2011; Karsai \& Knisley, 2009). Students with a sturdy base of quantitative understanding may find themselves bored during these portions of their undergraduate course, while students who were not 
Table 2. Goals related to quantitative skill development (BIO2010) and how to improve perception and appreciation of the quantitative biology field (Aikens and Dolan, 2014).

\begin{tabular}{|c|c|}
\hline NRC Goals & Aikens and Dolan Goals \\
\hline $\begin{array}{l}\text { Demonstrate quantitative numeracy and facility with } \\
\text { the language of mathematics }\end{array}$ & $\begin{array}{l}\text { More positive emotional responses to quantitative work, } \\
\text { such as greater enjoyment or reduced anxiety }\end{array}$ \\
\hline $\begin{array}{l}\text { Interpret data-sets and communicate those interpreta- } \\
\text { tions using visual and other appropriate tools }\end{array}$ & $\begin{array}{l}\text { More positive beliefs about the ability to do quantitative } \\
\text { work, such as increased confidence and self-efficacy }\end{array}$ \\
\hline Make statistical inferences from data-sets & Increased interest in quantitative work \\
\hline Extract relevant information from large data-sets & $\begin{array}{l}\text { Greater sense of the centrality of mathematics, statistics, } \\
\text { and computation to the practice of life science, including } \\
\text { their relevance and importance }\end{array}$ \\
\hline $\begin{array}{l}\text { Make inferences about natural phenomena using } \\
\text { mathematical models }\end{array}$ & Improved ability to work in interdisciplinary teams \\
\hline $\begin{array}{l}\text { Apply algorithmic approaches and principles of logic } \\
\text { (including the distinction between cause/effect and } \\
\text { association) to problem solving } \\
\text { Quantify and interpret changes in dynamical systems }\end{array}$ & $\begin{array}{l}\text { Increased intentions to pursue or actual pursuit of } \\
\text { further education and careers in quantitative biology }\end{array}$ \\
\hline
\end{tabular}

exposed to these methods may find themselves overwhelmed (Haak et al., 2011). Studies have shown negative correlation between math anxiety, math achievement, and student success in science, technology, engineering, and mathematics (STEM) fields (Chiel et al., 2010). Therefore, when quantitative methods are presented to introductory biology students, there could potentially be gaps in achievement between students from different educational backgrounds. This disconnect could be remedied using technologies that allow students to move at their own pace through quantitative modules, but there is still a need to address the lack of quantitative biology requirements at the secondary level (Brewer, 2003; Comar, 2013; Mayes, Luebeck, Ku, \& Korkmaz, 2011).

To combat differing levels in quantitative exposure, we recommend that all secondary schools improve integration of quantitative methods and biological processes into their curricula, using technology as an effective teaching tool. Secondary schools have used technology to help improve learning gains of students in Biology and other disciplines (Incantalupo, Treagust, \& Koul, 2014). For example, Ross, Morrison, and Lowther (2010) reviewed literature that supported effectiveness of technology in education. They found that when technology is integrated as a learning tool, not only are students' attitudes more positive, but students' skills in problem-solving, writing and higher order learning also increase. Ross et al. (2010) also address, however, that the effectiveness of technology interventions will depend on the application of said technology. Unfortunately, many secondary school educators do not feel confident in their own mathematics abilities or use of technology, and therefore shy away from teaching quantitative topics (Beilock, Gunderson, Ramirez, \& Levine, 2010; Jackson \& Leffingwell, 1999). This not only prevents students from gaining valuable knowledge, it can also introduce or increase math anxiety (Beilock et al., 2010; Drier, Harper, Timmerman, Garofalo, \& Shockey, 2000; Ertmer, Ottenbreit-Leftwich, Sadik, Sendurur, \& Sendurur, 2012; Jackson \& Leffingwell, 1999; $\mathrm{Li}, 2007)$. At the undergraduate level, biology professors usually have higher levels of quantitative ability but face uncertainty as to how quantitative topics can fit into the curriculum (Chiel et al., 2010; Waldrop et al., 2015). Using many of the resources presented in this paper, secondary educators can use previously developed resources as a means to teach quantitative biology methods without intimidation. 
There exist a wealth of resources to improve integration of these two disciplines, many of which use technology as a learning and skill-development tool. To encourage knowledge retention and understanding, available resources include: online instruction, simulation software, in-class clickers, Web-based discussion boards and others (Brewer, 2003; Chiel et al., 2010; Colon-Berlingeri and Burrowes, 2011; Feser et al., 2013; Gross, Pietri, Anderson, Moyano-Camihort, \& Graham, 2015; Haak et al., 2011; Mayes et al., 2011; Thompson et al., 2010; Waldrop, 2001; Waldrop et al., 2015). In this paper, we review how technology is being used to teach quantitative biology at the secondary and undergraduate levels, identify potential barriers to integrating these new topics into existing courses and curriculum, and propose resolutions to these barriers. We focus solely on the integration of quantitative topics in biology courses, rather than the inclusion of biological content in mathematics courses.

\section{Secondary education}

\subsection{The Common Core}

The Common Core State Standards are a set of English and Mathematics standards created for students in kindergarten through 12th grade (K-12) to help prepare them for two- to four-year college programmes or to enter the workforce (National Governors Association Center, 2016a, 2016b). Forty-two states have adopted the Common Core and have begun to implement their standards (National Governors Association Center, 2016b); states which have not adopted the Common Core as of 2015 include Alaska, Indiana, Minnesota, Nebraska, Oklahoma, South Carolina, Texas and Virginia (National Governors Association Center, 2015). The high and consistent standards across states and the clear expectations provided by the Common Core will prepare students to collaborate and compete with their peers throughout the United States and abroad (National Governors Association Center, 2016b).

The elementary school (K-5) mathematics standards aim to create a solid foundation in mathematics, to support student learning ability and to prepare students to apply more challenging math procedures and concepts (National Governors Association Center, 2010, 2016b). Once students reach middle school (6-8) and high school (9-12), standards aim to apply 'mathematical ways of thinking to real world issues' (National Governors Association Center, 2010, 2016b). Table 3 indicates the mathematical practices and skills emphasized by the Common Core. Previous studies have utilized some of these practices/skills in other fields and observed positive student learning outcomes (Chan, Hom, \& Montclare, 2011; Williams \& Linn, 2002). In fact, these skills are increasingly essential to many fields of science, including quantitative biology.

Online evaluations of the Common Core, effective in the 2014-2015 school years, will be used to determine if students are making the appropriate progress toward attaining the skills necessary to succeed after graduation (National Governors Association Center, 2016b). A 2013 national survey conducted by the University of Phoenix College of Education found that 81 percent of full-time K-12 educators cited various benefits of the Common Core (University of Phoenix, 2014). For example, educators found that the Common Core acts as a benchmark of student progress, applies to real world scenarios and encourages knowledge sharing among educators (University of Phoenix, 2014). Generally, each state has defined criteria for measuring adequate yearly progress of its school systems, and the 
Table 3. Recommended Common Core mathematical practices are shown in bold with further description in plain text (National Governors Association Center, 2010).

Mathematical practices/skills emphasized in the Common Core

\begin{tabular}{|c|c|}
\hline 1. & $\begin{array}{l}\text { Make sense of problems and persevere in solving them - determine the meaning of a problem and look for ways to } \\
\text { approach/arrive at the solution }\end{array}$ \\
\hline 2. & Reason abstractly and quantitatively - be able to decontextualize or contextualize when appropriate \\
\hline 3. & $\begin{array}{l}\text { Construct viable arguments and critique the reasoning of others - build and justify arguments based on the current } \\
\text { state of knowledge and be able to critique other arguments by asking 'does this make sense?' }\end{array}$ \\
\hline 4. & Model with mathematics - be able to relate math to real world issues \\
\hline 5. & Use appropriate tools strategically - recognize what can be gained from each tool and its limits \\
\hline & Attend to precision - use clear language when communicating concepts, procedures, and their own reasoning \\
\hline 7. & $\begin{array}{l}\text { Look for and make use of structure/patterns - address problem from different perspectives and can help when } \\
\text { reasoning through improbable solutions }\end{array}$ \\
\hline 8. & $\begin{array}{l}\text { Look for and express regularity in repeated reasoning - calculations are repeated and so allow students to identify } \\
\text { general methods and shortcuts }\end{array}$ \\
\hline
\end{tabular}

results from these assessments are used to determine disbursement of federal funding Shields et al. (2004). The vast majority of states use standardized tests to assess progress, but some states supplement these tests with other qualitative assessments (Shields et al., 2004). Despite the positive results of Common Core Assessments thus far, parents appear to have a different perspective of the curriculum (Otten \& De Araujo, 2015). A divide has formed between parents and teachers due to differing expectations and perceptions of specific Common Core methodologies (Otten \& De Araujo, 2015). Current accountability policies can be counterproductive to the success of Common Core standards. One example is that standardized tests can often lead to schools being labeled as 'failing' which can result in the dismissal of competent principals and teachers (Welner, 2014). To the authors' knowledge, no formal assessments have been made among states that have implemented the Common Core. This could be due to the fact that each state that has adopted the Common Core determines how their students will be assessed; so, although the standards are clearly defined, overall assessment is not.

\subsection{Advanced Placement (AP) courses}

AP courses are taken by high school students in an effort to receive college-level credit before graduation (The College Board, 2015). In the past few years, changes have been made to the AP Biology curriculum framework. Previously, the emphasis of AP Biology courses was on simple content coverage or factual recall (The College Board, 2015). However, the redesigned AP Biology courses have shifted that focus to include the utilization of inquiry-based investigations and computational tools in an effort to help students develop skills such as reasoning, data collection and analysis, communication, and the ability to connect and relate knowledge that can then be applied to solve real-world problems (Taylor, Campbell, \& Heyer, 2013; The College Board, 2015). The AP Biology curriculum focuses on five components to connect concepts across disciplines and facilitate deeper learning by providing: (1) the underlying content, (2) illustrative examples, (3) exclusion statements (i.e. details that do not promote student understanding), (4) concept and content connections and (5) clear learning objectives.

Some sections of the AP Biology curriculum have incorporated the repeated use of quantitative skills (e.g. manipulating and summarizing data, conducting and interpreting 
statistical analyses, justifying conclusions) in conjunction with experimental or observational studies and technology (Schultheis \& Kjelvik, 2015; Small \& Newtoff, 2013). AP courses are one possible avenue to ease the transition that occurs between secondary school and college. In fact, AP courses have been identified as a gateway to success in college by reducing the cost and time required to obtain a degree while increasing college graduation rates and the likelihood of students pursuing a graduate degree (Barnard-Brak, McGahaGarnett, \& Burley, 2011; Dougherty, Mellor, \& Shuling, 2006; Hargrove, Godin, \& Dodd, 2008; The College Board, 2015). Unfortunately, not all high schools have AP programmes available to students.

\subsection{Using technology as a teaching tool}

Many aspects of modern science have resulted in the combination of biological research with computer science. Many students, especially those in high school, are unaware of this important connection (Gallagher, Coon, Donley, Scott, \& Goldberg, 2011). The demand, and need, to introduce quantitative biology to students prior to beginning undergraduate study has grown enormously (Chan et al., 2011; Gallagher et al., 2011; Goodman \& Dekhtyar, 2014; Magana et al., 2014; McClatchy, McGann, Gotwals, Baskett, \& Churchill, 2013; Schneider et al., 2012). Fortunately, science educators have access to many types of resources.

\subsubsection{Open source technology and curriculum materials}

Some resources require a significant monetary investment (e.g. computers or software) from either the school or teacher (Goodman \& Dekhtyar, 2014; Hays, 2001). However, there are free, open source technologies that can be used when attempting to integrate quantitative skills in the biology classroom. For example, when Goodman and Dekhtyar employed an 'in-concert' teaching approach, where two distinct courses are taught in a concerted way, to their life-science (BIO) and computer science (CS) courses, they used the available resources from a federally-funded programme, the Genomics Education Partnership (GEP, http://gep.wustl.edu). Their students took problems related to annotation and comparative analysis of fruit fly genomes, and required BIO and CS students to work together using these online activities. These resources allow students to develop the skills needed to identify and analyse problems using computational tools without incurring added cost (Goodman \& Dekhtyar, 2014). Accessibility to this new open source technology makes it feasible to teach multiple aspects of quantitative biology in the high school classroom and can give students a greater sense of interest, engagement and selfefficacy (Incantalupo et al., 2014; Ross et al., 2010).

Practicing educators and researchers have developed a variety of free materials in an effort to begin incorporating quantitative biology in high school classes outside of AP. Some of these resources include: teaching tips and activities that reinforce concepts in bioinformatics (Form \& Lewitter, 2011; Gelbart, Brillm, \& Yarden, 2008; Taylor et al., 2013), activities and modules on interpreting 'messy' data (Schultheis \& Kjelvik, 2015), activities and modules that expose students to the unpredictability of real science (Schultheis \& Kjelvik, 2015), cloud labs (Hossain et al., 2016), modules for computational biology (Gallagher et al., 2011; McClatchy et al., 2013) and gamebased curricula (which has been shown to be effective across all secondary academic 
levels; Sadler, Romine, Stuart, \& Merle-Johnson, 2013). Some instructors may only use one of these resources while others chose to take a more comprehensive approach. As a researcher at the Center for Genomic Dynamics, McClatchy et al. (2013) created an immersive module taught over one academic year. High school students performed the activities of a systems biologist including literature review, formulation and testing of hypotheses, statistical analysis, employment of computational tools, grant writing and publication of student work. Gelbart et al. (2008) used a web-based research simulation tool to help high school students learn genetics and found that there was a significant increase in the abilities of students to answer both true/false and comprehension-based questions after simulation-based learning in comparison to students learning from the textbook.

\subsubsection{Achieving Modeling Core competencies using technology}

Numerous online open source tools allow teachers to provide highly interactive instruction while also providing students the opportunity to solve real-world problems and build skills to help them in their future college studies (Cummings \& Temple, 2010; Form \& Lewitter, 2011). The National Academy of Sciences (NAS) has recently called for incorporation of modeling skills as a core competency in the K-12 framework for science education (National Research Council, 2012). This goal comes with its own difficulties (e.g. no consensus on what models are, how to develop modeling skills while also delivering content; Manthey \& Brewe, 2013), but the Society of Industrial and Applied Mathematics (SIAM) offers mathematical modeling workshops which have been known to provide guidance with some of these issues. Fortunately, the Common Core has included modeling as a component of high school mathematics standards (National Governors Association Center, 2010); therefore, less of a learning curve should be observed for students using modeling skills in other courses. Modeling modules have been used in course topics like evolutionary biology (Passmore and Stewart, 2002), biomedical science (Malanson, Jacque, Faux, \& Meiri, 2015), and microbiome research (Cobb and Gillevet, 2014). For example, Cobb and Gillevet (2014) created a thorough teachers guide, which is available for use with high school students. This guide allows for participation in microbiome research and includes the creation of models, sample processing and use of computational tools for analysis.

There are multiple technological tools available to educators that can be used to enhance existing curricula. Taylor et al. (2013) present a free online tool that introduces advanced high school students to bioinformatics through exploring the genome assembly process and learning how mathematics can help to solve biological problems. Similarly, Schultheis and Kjelvik (2015) discuss the availability of Data Nuggets, a set of free K-16 educational resources that bring real data collected by scientists into the classroom. The accompanying worksheets and modules help to get students excited about research through building graphs and interpreting data. Simultaneously, students are improving their understanding of the scientific method and quantitative skills. Hossain et al. (2016) created a cloudbased biology experimentation platform that can be used for students as young as middle school. Using a web interface, students test the directional movement of Euglena gracilis in response to light. The authors tested this platform in three different educational groups and found that the platform can successfully be implemented at multiple educational levels. 
Though these tools have not been formally assessed, they do show promise at improving skills and attitudes towards mathematical modeling.

\subsubsection{Overcoming issues with technology}

There is still much to learn about how to overcome issues related to technology implementation and use, setting appropriate expectations for secondary school students and how to adjust preexisting expectations accordingly. To address technology related issues, the U.S. Department of Education (DOE) has provided a thorough publication on technology in schools. Some particularly useful sections include technology applications, professional development and technology integration (NCES, 2002; Yigal et al., 2015). For example, in an attempt to demonstrate to students how computation is used in biology and how it is necessary for biological research, Gallagher et al. (2011) introduced the use of algorithms to compare DNA sequences and methods for building phylogenetic trees to three secondary school advanced-biology classrooms. In discussions with the classroom teachers post-lesson, Gallagher et al. (2011) discovered that students could use existing algorithms but struggled to write their own, and that students were uncomfortable with open-ended activities, preferring a more structured activity that did not leave them feeling directionless. Students in AP Biology courses (one of the three classes) felt pressure to perform well on their exams, and therefore felt that spending time on non-exam material was a 'waste of time' or a 'distraction.' This is a serious problem considering the importance of these tools to many practicing researchers. By conducting a study such as this, researchers and instructors are able to recognize and adjust for these perceived challenges for future iterations of their course. For instance, in convincing students of the connection between computer science and biology, researchers proposed bringing in working biologists who use computational skills into the classroom. Although Gallagher et al. (2011) faced these hurdles in integrating greater use of technology into the curriculum; the majority of students did recognize the importance of computer science to biological research.

The ability of students to connect computer science, mathematics and biology will be essential to their success in the practice of most modern sciences. Teachers will be the pipelines that connect science at universities to their students in the high school classroom, hopefully inspiring the next generation of scientists. It is equally important to ensure teachers are confident in their own ability to understand and teach the material (Borgerding, Sadler, \& Koroly, 2013; Kovarik et al., 2013). Therefore, training and professional development of secondary instructors will be essential to keep them abreast of the current status of quantitative biology (Hew \& Brush, 2007; Jungck \& Weisstein, 2013; Kovarik et al., 2013; Magana et al., 2014; Sorgo, 2010; Waight \& Abd-El-Khalick, 2011; Willingale-Theune et al., 2009; Wood \& Gebhardt, 2013).

\section{Post-secondary education}

\subsection{Quantitative literacy in undergraduate classrooms}

The development of quantitative literacy skills in post-secondary students is becoming increasingly emphasized. With the explosion and availability of 'big data' (i.e. large, real datasets), the demand for individuals highly trained in statistics, mathematics and modeling will be necessary in many life science disciplines (Cummings \& Temple, 2010; Labov, Reid, \& Yamamoto, 2010). Undergraduate institutions and their educators strive 
to continually improve the quantitative literacy of life science students through the implementation of new tools and techniques (Colon-Berlingeri \& Burrowes, 2011; Gelbart et al., 2008; Grisham, Schlotter, Valli-Marill, Beck, \& Beatty, 2010). These strategies often focus on increasing mathematical and statistical skills. Such strategies include the use of simulations (Aegerter-Wilmsen \& Bisseling, 2005), Web-based teaching modules (e.g. BioQuest, MathBench; Feser et al., 2013; Grisham et al., 2010; McClatchy et al., 2013; Thompson et al., 2013), and the integration of quantitative activities or data-driven problems in existing biology courses (Cummings \& Temple, 2010; Small \& Newtoff, 2013; Usher et al., 2010). Employing active learning in the classroom has also been used to introduce new concepts and methods in quantitative biology (Haak et al., 2011). For example, North Carolina State University developed the SCALEUP Project, which replaced the common laboratory/lecture set-up with a physical, group-based workspace used for active learning (Waldrop et al., 2015). Although these techniques have been well documented, assessments of these strategies have been undertaken only recently.

\subsection{Using online resources to increase quantitative literacy in the classroom}

Today, undergraduate institutions across America are increasingly utilizing technology in their approach to teaching quantitative skills and methods (Feser et al., 2013; Jungck et al., 2010; Speth et al., 2010; Thompson et al., 2010). Over the last 15 years, online resources (e.g. learning modules, data-sets) have been developed and compiled for educators to integrate into course topics from bioinformatics to zoology (Colon-Berlingeri \& Burrowes, 2011; Cummings \& Temple, 2010). Technology has been an effective tool used to sustain student engagement in learning activities, particularly in concepts or topics that may traditionally be perceived as difficult (e.g. mathematics, computer science; Cummings \& Temple, 2010). Technological usage includes simulations, applications of distance education, Internet access, and educational games via computers or smart phones (Ross et al., 2010). Three main technological resources have arisen for use in teaching quantitative biology: (1) open source online software and resources; (2) free online teaching modules; and (3) open access to 'big data.' In an effort to increase quantitative literacy, some undergraduate science courses have incorporated an online component. Some of these components include online learning communities, real-time assessments, lectures and in-class activities (Brewer, 2003; Jungck, 2012; Karsai \& Knisley, 2009; Waldrop, 2001; Waldrop et al., 2015). Large funding agencies such as the National Science Foundation (NSF) have also been supporting this movement in improving quantitative literacy in biology undergraduate classrooms. For example, the NSF-funded Quantitative Undergraduate Biology Education and Synthesis (QUBES, https://qubeshub.org) project aims to improve learning opportunities for undergraduate biology students through increased quantitative approaches in biology. QUBES maintains a 'Hub' which amalgamates resources to support educators and researchers in teaching, research and networking in quantitative biology. The Hub can be used to promote collaboration between post-secondary institutions to share activities in teaching quantitative biology. Efforts such as these show promise and have been met with some success. Other review articles have examined and compiled these online resources (Aikens \& Dolan, 2014; Feser et al., 2013; Magana et al., 2014); however, many tools and their assessments are still in development. 


\subsubsection{Online software and resources}

Free online software has been employed in many classroom activities in an effort to help students develop quantitative skills. In the field of bioinformatics, improvement of student quantitative literacy comes primarily through use of new software (Badotti et al., 2014; Dauer, Momsen, Speth, Makohon-Moore, \& Long, 2013; Jungck et al., 2010). For example, to improve modeling and mathematical analysis skills in students, Chiel et al. (2010) utilized Mathematica in their Dynamics of Biological Systems course. While Mathematica software is not free, the institution invested in a license, which allowed their students to each have their own copy. In the post-assessment of this course, the authors found that student willingness and ability to use modeling tools and mathematical concepts to comprehend biological systems significantly increased. This is one of many examples of educators using existing software to enhance student quantitative literacy. Other online resources (e.g. Web portals, teaching material hubs) have also been used to improve quantitative education for undergraduate students (Schneider et al., 2012; Wightman \& Hark, 2012).

\subsubsection{Online teaching modules}

The use of free, interactive web-based modules has also been growing in undergraduate classrooms to improve student quantitative literacy (Grisham et al., 2010). Online modules, or single lessons taken from modules, are often used in conjunction with existing curricula. Suites of interactive modules, such as those provided in MathBench, have been particularly successful in improving quantitative literacy for biology students. Developed by the University of Maryland, College Park, MathBench consists of 37 self-contained learning modules that use colloquial language to combat math anxiety and build on the students pre-existing knowledge of math. Feser et al. (2013) and Thompson et al. (2013) have used the biology modules in MathBench to encourage students to understand various biology topics through a quantitative lens. Using pre- and post-tests, Thompson et al. (2010) found that students who had used MathBench in their Introductory Cell and Molecular Biology coursework experienced significant improvements in their quantitative skills over the semester and had greater appreciation for mathematics in a biological context. Speth et al. (2010) also incorporated quantitative concepts (e.g. data driven problems, graphing data) within online learning modules, allowing them to respond quickly to their student's learning needs during a large-enrollment introductory biology course. Compared to pre-tests assessing students initial quantitative literacy skills, post-test scores demonstrated that this approach increased student graphing skills and performance in conducting simple calculations within the semester. Despite the lack of control groups for comparison, the proportion of undergraduate students who demonstrate and report learning gains cannot be dismissed. Nevertheless, studies that have control groups report similar findings. For example, Physics and Physiology education researchers utilizing an online-component reported significant learning gains and satisfaction of students (Dori \& Belcher, 2005; Taradi, Taradi, Radic, \& Pokrajac, 2005). Students may experience significant improvements to their quantitative skills when educators integrate modules or single lessons into the curriculum, as evidenced by these studies.

\subsubsection{Integrating 'Big Data'}

Research using large data-sets is growing in the field of biology, yet the skills and tools necessary to process these data-sets is something even current researchers in many fields 
may find challenging. Some educators have integrated larger datasets into classrooms and laboratories in an effort to improve student quantitative skills at undergraduate and graduate-levels (Makarevitch, Frechette, \& Wiatros, 2015; Schultheis \& Kjelvik, 2015; Stefan, Gutlerner, Born, \& Springer, 2015). For instance, Makarevitch et al. (2015) developed research laboratory activities for an introductory undergraduate classroom, which incorporated RNA-seq analysis. In these activities, students were asked to analyse gene expression changes of maize seedlings in response to abiotic stresses and perform data analysis in the R-language environment. Pre- and post-test assessment of students revealed significant learning gains in data analysis skills (e.g. graphical data visualization and interpretation) and in understanding the scientific method. As the trajectory of life science disciplines continue towards the utilization of large biological datasets, it is necessary for students interested in a science career to be comfortable and knowledgeable when employing these tools (Handelsman et al., 2004). By making these tools accessible to all students, we can increase scientific literacy from a post-secondary level.

\subsection{Current limitations}

While the number of initiatives aiming to integrate quantitative skills into the biology classroom have increased, the effectiveness of these tools and the changes in curricula have not always been assessed. For example, in a new Quantitative Biology B.S. degree programme at the University of Delaware, students are required to take core courses from biology to physics, with a mathematics emphasis (Usher et al., 2010). It still remains unclear if students in these courses are truly gaining greater knowledge and literacy in quantitative methods, although the dedication and resource efforts being funneled into these initiatives are admirable. Without a control group, it is difficult to ascertain if student-learning gains are due to the technological addition into the curriculum. Those assessing quantitative literacy gains in their students should also include effect sizes (e.g. Pearsons $r$ or $\eta^{2}$ ) to be confident that these gains are attributed to the use of technology (Maher, Markey, \& Ebert-May, 2013). Aikens and Dolan (2014) suggest that increased collaborations between quantitative biologists and education researchers may help develop broader and more effective assessment tools. For example, Incantalupo et al. (2014) developed a validated instrument to measure students attitudes and knowledge of technology, with the goal of investigating any gender differences after the use of technology was incorporated into teaching a high school biology course. Instruments such as this can be used by researchers interested in determining the effectiveness or change in attitude of their use of technology in their teaching.

The burden of equipping students with quantitative skills has fallen purely on educators, typically on a per course basis (Colon-Berlingeri \& Burrowes, 2011; Jungck et al., 2010; Speth et al., 2010). More frequent and accessible professional development opportunities for faculty can promote undergraduate student learning by introducing new teaching methods and technologies (National Research Council, 2003). For example, in the last decade, the Mathematical Association of America (MAA), the Mathematical Biosciences Institutes (MBI), the National Institute for Mathematical and Biological Synthesis (NIMB), the National Computational Science Institute (NCSI), the National Institute for Mathematical and Biological Synthesis (NIMBioS), and QUBES, among many others, have sponsored and continue to sponsor faculty development workshops. Online platforms and mentor- 
ing networks for faculty interested in incorporating more quantitative biology in their classrooms are also supported through federally funded projects such as QUBES. Faculty advocacy within an institution is necessary to see improvement in student quantitative literacy through technology. However, they must first be convinced that these skills are integral to the success of young scientists and that there will be support for their efforts, particularly at an institutional level. For example, greater infrastructure, accessibility to resources, and increased training opportunities for educators can lead to increased student quantitative literacy (Cummings \& Temple, 2010).

\section{Looking to the future}

As the scientific community strives to produce well-rounded scientists and greater scientific literacy in the overall population, we cannot ignore the need for understanding quantitative methods as they apply to biology (Aikens \& Dolan, 2014; Bialek \& Botstein, 2004; Handelsman et al., 2004; Waldrop et al., 2015). The ubiquity of technology, especially open source content, makes it a helpful tool in teaching these methods to students at the secondary and post-secondary levels. If secondary programmes adopt a common set of goals concerning quantitative biology education and effectively implement the material into existing curriculum, post-secondary students will share the same level of exposure to and positive attitudes about quantitative biology methods (Aikens \& Dolan, 2014; Bialek \& Botstein, 2004; Karsai \& Knisley, 2009).

\section{Barriers to implementing quantitative biology education}

We understand there are barriers to integrating mathematics and biology at the secondary and post-secondary levels. Many of these challenges are shared between these institutional levels, but they also encounter their own unique barriers.

One of the main barriers institutions may experience is student pushback (Bialek \& Botstein, 2004; Waldrop, 2001). When the subject matter of mathematics and biology has been historically separated, the unfamiliarity of the integrated subject matter may cause students to 'freak out' initially (Bialek \& Botstein, 2004; Haak et al., 2011; Usher et al., 2010; Waldrop, 2001). Pushback also occurs because students do not understand the importance of learning new methods with which to observe biological systems (Aikens \& Dolan, 2014; Usher et al., 2010). An advantage of introducing the integration of mathematics and biology early in students educational pursuits is that it remedies the unfamiliarity of subject matter, but there are also other methods of reducing anxieties around mathematics in biology. One course of action is to encourage students to continue working through the provided activities, despite their discomfort (Waldrop, 2001). If the activities are graded for completeness rather than correctness in the beginning, it can help to familiarize students with the technology and quantitative aspects of their assignments without unduly stressing the importance of getting a right answer (Donovan, 2001; Waldrop, 2001). Another option is to choose appropriate software suites that use familiar and informal language to combat anxiety from overuse of jargon (Thompson et al., 2010). Finally, instructors can start with lower-level mathematics (e.g. algebraic models) to ease the transition into incorporating higher level quantitative methods into biology courses (Robeva \& Laubenbacher, 2009). 
Monetary constraints are present at both levels, but may be more apparent at the secondary level. Incorporating technology requires funds for computers, clickers, software licenses or other equipment, but not all schools have access to these materials (Brewer, 2003; Haak et al., 2011; Mayes et al., 2011; Thompson et al., 2010; Waldrop et al., 2015). Additionally, there is an apparent 'digital divide' between low-income students and their middle-income counterparts that mainly manifests itself in out-of-school access to technology (Celano \& Neuman, 2013). As a remedy, we suggest that instructors use these tools to present quantitative biology methods to students in class, but ensure any takehome work does not require direct use of technology. Luckily, many available tools for teaching quantitative biology are open-source and therefore do not require any monetary contribution to be useful in classrooms (Feser et al., 2013). Another solution is to increase technological funding in low-income schools, but we understand the need for individuallevel options since increasing overall funding is challenging.

At the secondary level, we see greater curriculum inflexibility than that at the undergraduate level. With programmes like Common Core and AP, combined with other state standards, incorporating new units into a rigid curriculum may seem impossible. Fortunately, the Common Core Standards and AP tests have recently incorporated quantitative aspects into their curriculum (Mayes \& Koballa, 2012; Jungck et al., 2010). These concepts can be made more accessible and engaging to students through the use of available technology. There are many freely available modules that present appropriate information and activities to teach concepts in quantitative biology (Aikens \& Dolan, 2014; Feser et al., 2013; Jungck \& Weisstein, 2013; Thompson et al., 2010; Waldrop et al., 2015). The increased availability of resources and the inclusion of these topics in widely used standards may resolve some the issues associated with curriculum inflexibility.

Teachers, especially at the secondary level, can also fall victim to math anxieties that can exacerbate those of their students (Jackson \& Leffingwell, 1999). Teacher pushback can therefore be a barrier to implementation of these methods. Using available and cohesive materials can help decrease preparation for teachers, but they must also understand the concepts they are presenting and be confident in their abilities for student learning to be effective. There are workshops available to refresh and improve the quantitative skills of science teachers at both secondary and post-secondary (e.g. workshops and resources from MAA, NCSI, MBI, QUBES, NIMBioS) levels. Increased attendance at these workshops and access to all-inclusive online materials (e.g. lecture slides, activity descriptions, worksheets) may help increase confidence and decrease the burden of teacher preparation (Waldrop et al., 2015).

Institutional pushback may be observed at the undergraduate level. Despite the recommendations of BIO2010, some institutions may be unwilling to allocate resources to increase the incorporation of mathematical methods in life science courses, although differences may be observed between smaller and larger institutions (Chiel et al., 2010; Marsteller et al., 2010). In response to this, we encourage faculty members to present BIO2010 and the goals of Aikens and Dolan (2014) to show the importance of having both the appropriate skills and attitudes in regard quantitative biology methods (National Research Council, 2003); combined with numerous case studies (e.g. Feser et al., 2013; Speth et al., 2010; Thompson et al., 2010) outlining the long-term importance of these skills, we believe many doubts will be resolved. 
Once the institution has been convinced that interdisciplinary courses are necessary, the development of new courses, degrees and curricula can be daunting (Marsteller et al., 2010; Usher et al., 2010). This is especially tricky when planning for large class sizes. One option is to use existing materials and case studies, whose methodologies have proved successful, to create new courses. To bolster the available resources and provide an outlet for discussion of common issues, there are workshops strictly for creating these interdisciplinary courses as well as online discussion boards and forums that can help resolve issues remotely (Waldrop et al., 2015).

\section{Conclusions}

In this paper, we have reviewed the uses of technology to teach quantitative biology methods at the secondary and undergraduate levels. We also addressed common barriers and proposed solutions to effectively integrate quantitative skills into biology courses. While there are numerous resources (e.g. Feser et al., 2013; Speth et al., 2010; Thompson et al., 2010) available for teaching undergraduate students these skills, there is a need to improve the accessibility of these tools to secondary students. Along with the need for additional resources, we also posit that better assessments of courses at both levels are especially necessary. Overall, improving institutional perceptions of these topics will result in the implementation of quantitative biology methods at all levels. The need for these skills and methodologies is apparent not only in biology, but also in many other scientific disciplines. To build a well-rounded generation of interdisciplinary scientists, exposure to quantitative biology methods must begin earlier in the educational pursuits of students. Introducing these topics at earlier educational levels using technology can help to alleviate mathematics anxiety and can inspire and improve retention of students in STEM majors.

\section{Acknowledgements}

We would like to thank Dr Elisabeth E. Schussler, Dr Louis J. Gross, Dr Benjamin England, and two anonymous peers for their edits to the earlier versions of the manuscript, and Dr Olcay Akman and the anonymous reviewers who have provided feedback to improve this manuscript.

\section{Disclosure statement}

No potential conflict of interest was reported by the authors.

\section{Funding}

This work was supported by the Department of Ecology and Evolutionary Biology at the University of Tennessee, Knoxville. S. M. Scott is funded by NIH/NIGMS - IMSD [grant number \#R25GM086761].

\section{ORCID}

Miranda M. Chen (D) http://orcid.org/0000-0001-8217-4896 


\section{References}

Aegerter-Wilmsen, T., \& Bisseling, T. (2005). Biology by Numbers - introducing quantitation into life science education. PLOS Biology, 3(1), doi:10.1371/journal.pbio.0030001

Aikens, M. L., \& Dolan, E. L. (2014). Teaching quantitative biology: Goals, assessments, and resources. Molecular Biology of the Cell, 25(22), 348-3481.

Badotti, F., Barbosa, A. S., Reis, A. L. M., do Valle, I. F., Ambrosio, L., \& Bitar, M. (2014). Comparative modeling of proteins: A method for engaging students' interest in bioinformatics tools. Biochemistry and Molecular Biology Education, 42(1), 68-78.

Balter, O., Enstrom, E., \& Klingenberg, B. (2013). The effect of short formative diagnostic web quizzes with minimal feedback. Computers \& Education, 60(1), 234-242. Retrieved from http:// www.sciencedirect.com/science/article/pii/S0360131512002047

Barnard-Brak, L., McGaha-Garnett, V., \& Burley, H. (2011). Advanced placement course enrollment and school-level characteristics. NASSP Bulletin, 95(3), 165-174. doi:10.1177/0192636511418640

Beilock, S. L., Gunderson, E. A., Ramirez, G., \& Levine, S. C. (2010). Female teachers math anxiety affects girls math achievement. Proceedings of the National Academy of Sciences, 107(5), 18601863. Retrieved from http://www.pnas.org/content/107/5/1860.abstract

Bialek, W., \& Botstein, D. (2004). Introductory science and mathematics education for 21st-century biologists. Science, 303(5659), 788-790. Retrieved from http://science.sciencemag.org/content/ 303/5659/788

Borgerding, L. A., Sadler, T. D., \& Koroly, M. J. (2013). Teachers' concerns about biotechnology education. Journal of Science Education and Technology, 22(2), 133-147. doi:10.1007/s10956-012-9382-z

Brewer, C. A. (2003). Computers in the classroom: how information technology can improve conservation education. Conservation Biology, 17(3), 657-660. doi:10.1046/j.1523-1739.2003.01739.x

Celano, D., \& Neuman, S. B. (2013). Low-income children lack digital resources. In J. Bartos (Ed.), At issue. What is the role of technology in education? Detroit: Greenhaven Press. (Reprinted from Educational Leadership, 2010, November). Retrieved from http://link.galegroup.com/apps/doc/ EJ3010836204/OVIC?

Chan, Y. M., Hom, W., \& Montclare, J. K. (2011). Implementing and evaluating mentored chemistrybiology technology lab modules to promote early interest in science. Journal of Chemical Education, 88(6), 751-754.

Chapman, B. S., Christmann, J. L., \& Thatcher, E. F. (2006). Bioinformatics for undergraduates: Steps toward a quantitative bioscience curriculum. Biochemistry and Molecular Biology Education, 34(3), 180-186. doi:10.1002/bmb.2006.49403403180

Chiel, H. J., McManus, J. M., \& Shaw, K. M. (2010). From biology to mathematical models and back: Teaching modeling to biology students, and biology to math and engineering students. CBE - Life Science Education, 9(3), 248-265.

Cobb, A., \& Gillevet, P. (2014). How can high school students combine computational biology tools with a laboratory model to analyze changes in the human gut microbiome? (EDU1P.247). The Journal of Immunology, 192(1 Supplement), 491-491. Retrieved from http://www.jimmunol.org/ content/192/1_Supplement/49.1

Colon-Berlingeri, M., \& Burrowes, P. A. (2011). Teaching biology through statistics: Application of statistical methods in genetics and zoology courses. CBE - Life Science Education, 10(3), 259-267.

Comar, T. D. (2013). Class projects using MATLAB to analyze models using impulsive differential equations. Proceedings of the 24th annual international conference on technology in collegiate mathematics, Orlando, FL.

Cummings, M. P., \& Temple, G. G. (2010). Broader incorporation of bioinformatics in education: Opportunities and challenges. Briefings in Bioinformatics, 11(6), 537-543.

Dauer, J. T., Momsen, J. L., Speth, E. B., Makohon-Moore, S. C., \& Long, T. M. (2013). Analyzing change in students' gene-to-evolution models in college-level introductory biology. Journal of Research in Science Teaching, 50(6), 639-659. doi:10.1002/tea.21094 
Donovan, S. (2001). Mining the databases and solving problems: Modeling biology learning on biology research. The institute of Learning Technology. Retrieved from http://www.bioquest.org/ modeling_learning_on_research.pdf

Dori, Y. J., \& Belcher, J. (2005). How does technology-enabled active learning affect undergraduate students' understanding of electromagnetism concepts? The Journal of the Learning Sciences, 14(2), 243-279.

Dougherty, C., Mellor, L., \& Shuling, J. (2006). The relationship between advanced placement and college graduation. Technical Report. Austin, TX: National Center for Educational Accountability.

Drier, H. S., Harper, S., Timmerman, M. A., Garofalo, J., \& Shockey, T. (2000). Promoting appropriate uses of technology in mathematics teacher preparation. Contemporary Issues in Technology and Teacher Education, 1(1), 66-88. Retrieved from https://www.learntechlib.org/ $\mathrm{p} / 10804$

Ertmer, P. A., Ottenbreit-Leftwich, A. T., Sadik, O., Sendurur, E., \& Sendurur, P. (2012). Teacher beliefs and technology integration practices: A critical relationship. Computers \& Education, 59(2), 423-435. Retrieved from http://www.sciencedirect.com/science/article/pii/S0360131512000437

Feser, J., Vasaly, H., \& Herrera, J. (2013). On the edge of mathematics and biology integration: Improving quantitative skills in undergraduate biology education. CBE-Life Sciences Education, 12(2), 124-128. Retrieved from http://www.lifescied.org/content/12/2/124.short

Form, D., \& Lewitter, F. (2011). Ten simple rules for teaching bioinformatics at the high school level. PLOS Computational Biology, 7(10), 1-2. doi:10.1371/journal.pcbi.1002243

Gallagher, S. R., Coon, W., Donley, K., Scott, A., \& Goldberg, D. S. (2011). A first attempt to bring computational biology into advanced high school biology classrooms. PLOS Computational Biology, 7(10), 1-7. doi:10.1371/journal.pcbi.1002244

Gelbart, H., Brillm, G., \& Yarden, A. (2008). The impact of a web-based research simulation in bioinformatics on students' understanding of genetics. Research in Science Education, 39(5), 725. doi:10.1007/s11165-008-9101-1

Goodman, A. L., \& Dekhtyar, A. (2014). Teaching bioinformatics in concert. PLoS Computational Biology, 10, e1003896.

Grisham, W., Schlotter, N. A., Valli-Marill, J., Beck, L., \& Beatty, J. (2010). Teaching bioinformatics and neuroinformatics using free web-based tools. CBE Life Science Education, 9(2), 98-107.

Gross, D., Pietri, E. S., Anderson, G., Moyano-Camihort, K., \& Graham, M. J. (2015). Increased preclass preparation underlies student outcome improvement in the flipped classroom. CBE-Life Sciences Education, 14(4). Retrieved from http://www.lifescied.org/content/14/4/ar36.abstract

Gross, L. J. (2000). Education for a biocomplex future. Science, 288(5467), 807-807. Retrieved from http://science.sciencemag.org/content/288/5467/807

Gula, T., Hoessler, C., \& Maciejewski, W. (2015). Seeking mathematics success for college students: A randomized field trial of an adapted approach. International Journal of Mathematical Education in Science and Technology, 46(8), 1130-1148. doi:10.1080/0020739X.2015.1029026

Haak, D. C., HilleRisLambers, J., Pitre, E., \& Freeman, S. (2011). Increased structure and active learning reduce the achievement gap in introductory biology. Science, 332(6034), 1213-1216. Retrieved from http://science.sciencemag.org/content/332/6034/1213

Handelsman, J., Ebert-May, D., Beichner, R., Bruns, P., Chang, A., DeHaan, R., ... Wood, W. B. (2004). Scientific teaching. Science, 304(5670), 521-522. Retrieved from http://science.sciencemag. org/content/304/5670/521

Hargrove, L., Godin, D., \& Dodd, B. G. (2008). College outcomes comparisons by AP and non-AP high school experiences. Non-journal. College Board.

Hays, R. (2001). Review. The American Biology Teacher, 63(2), 140-140. Retrieved from http://abt. ucpress.edu/content/63/2/140.2

Hennessy, S., Wishart, J., Whitelock, D., Deaney, R., Brawn, R., la Velle, L., ... Winterbottom, M. (2007). Pedagogical approaches for technology-integrated science teaching. Computers \& Education, 48(1), 137-152. Retrieved from http://www.sciencedirect.com/science/article/pii/ S0360131506000406 
Hew, K. F., \& Brush, T. (2007). Integrating technology into K- 12 teaching and learning: Current knowledge gaps and recommendations for future research. Educational Technology Research and Development, 55(3), 223-252.

Hossain, Z., Bumbacher, E. W., Chung, A. M., Kim, H., Litton, C., Walter, A. D., ... Riedel-Kruse, I. H. (2016). Interactive and scalable biology cloud experimentation for scientific inquiry and education. Nature Biotechnology, 34, 1293-1298.

Incantalupo, L., Treagust, D. F., \& Koul, R. (2014). Measuring student attitude and knowledge in technology-rich biology classrooms. Journal of Science Education and Technology, 23(1), 98-107. doi:10.1007/s10956-013-9453-9

Jackson, C. D., \& Leffingwell, R. J. (1999). The role of instructors in creating math anxiety in students from Kindergarten through College. The Mathematics Teacher, 92(7), 583-586. Retrieved from http://www.jstor.org/stable/27971118

Jungck, J. R. (2011). Mathematical biology education: Modeling makes meaning. Mathematical Modelling of Natural Phenomena, 6(6), 1-21. doi:10.1051/mmnp/20116601

Jungck, J. R. (2012). Incorporating quantitative reasoning in common core courses: Mathematics for the ghost map. Numeracy, 5(7), 1-30.

Jungck, J. R., Gaff, H. D., Fagen, A. P., \& Labov, J. B. (2010). Beyond BIO2010: Celebration and opportunities at the intersection of mathematics and biology. CBE-Life Sciences Education, 9(3), 143-147. Retrieved from http://www.lifescied.org/content/9/3/143.short

Jungck, J. R., \& Weisstein, A. E. (2013). Mathematics and evolutionary biology make bioinformatics education comprehensible. Briefings in Biomathematics, 14(5), 599-609.

Karsai, I., \& Knisley, J. (2009). The role of institutes in interdisciplinary research and education: An example from quantitative biology. Journal of College Science Teaching, 38(3), 32-37.

Kovarik, D. N., Patterson, D. G., Cohen, C., Sanders, E. A., Peterson, K. A., Porter, S. G., \& Chowning, J. T. (2013). Bioinformatics education in high school: Implications for promoting science, technology, engineering, and mathematics careers. CBE Life Science Education, 12(3), 441-459.

Labov, J. B., Reid, A. H., \& Yamamoto, K. R. (2010). Integrated biology and undergraduate science education: A new biology education for the twenty-first century? CBE-Life Sciences Education, 9(1), 10-16. Retrieved from http://www.lifescied.org/content/9/1/10.short

Lee, S. W.-Y., \& Tsai, C.-C. (2013). Technology-supported Learning in secondary and undergraduate biological education: Observations from literature review. Journal of Science Education and Technology, 22, 226-233.

Li, Q. (2007). Student and teacher views about technology: A tale of two cities? Journal of Research on Technology in Education, 39(4), 377-397.

Magana, A. J., Taleyarkhan, M., Alvarado, D. R., Kane, M., Springer, J., \& Clase, K. (2014). A survey of scholarly literature describing the field of bioinformatics education and bioinformatics educational research. CBE-Life Sciences Education, 13(4), 607-623. Retrieved from http://www. lifescied.org/content/13/4/607.abstract

Maher, J. M., Markey, J. C., \& Ebert-May, D. (2013). The other half of the story: effect size analysis in quantitative research. CBE-Life Sciences Education, 12(3), 345-351. Retrieved from http://www. lifescied.org/content/12/3/345.abstract

Makarevitch, I., Frechette, C., \& Wiatros, N. (2015). Authentic research experience and 'big data' analysis in the classroom: Maize response to abiotic stress. CBE Life Science Education, 14(3). pii: $\operatorname{ar} 27$.

Malanson, K., Jacque, B., Faux, R., \& Meiri, K. F. (2015). Modeling for fidelity: Virtual mentorship by scientists fosters teacher self-efficacy and promotes implementation of novel high school biomedical curricula. PLOS One, 9(12), 1-23. doi:10.1371/journal.pone.0114929

Manthey, S., \& Brewe, E. (2013). Toward university modeling instructionbiology: Adapting curricular frameworks from physics to biology. CBE-Life Sciences Education, 12(2), 206-214. Retrieved from http://www.lifescied.org/content/12/2/206.abstract

Marsteller, P., de Pillis, L., Findley, A., Joplin, K., Pelesko, J., Nelson, K., ... Watkins, J. (2010). Toward integration: From quantitative biology to mathbio-biomath? CBE Life Sciences Education, 9(3), $165-171$. 
Mayes, R. L., \& Koballa, T. R. (2012). Exploring the science framework: Making connections in math with the common core state standards. The Science Teacher, 79(9), 27-34.

Mayes, R., Luebeck, J., Ku, H. Y., \& Korkmaz, C. (2011). Themes and strategies for transformative online instruction: A review of literature and practice. In Global learn conference (Vol. 12, pp. 151-166). Melbourne, Australia.

McClatchy, S., McGann, D., Gotwals, R., Baskett, A., \& Churchill, G. (2013). Students as collaborators in systems biology research. Science, 340(6136), 1061-1062. Retrieved from http://science. sciencemag.org/content/340/6136/1061

National Governors Association Center. (2010). Common core standards initiatives - mathematics standards. online.

National Governors Association Center. (2015). Common core state standards - standards in your state. online.

National Governors Association Center. (2016a). Common core state standards initiatives development process. online.

National Governors Association Center. (2016b). Common core state standards initiatives frequently asked questions. online.

National Research Council. (2003). BIO2010: Transforming undergraduate education for future research biologists. Washington, DC: The National Academies Press.

National Research Council. (2012). A framework for K-12 science education: Practices, crosscutting concepts, and core ideas. Washington, DC: The National Academies Press.

NCES, National Center for Education Statistics, United States Department of Education. (2002). Technology in schools: Suggestions, tools, and guidelines for assessing technology in elementary and secondary education. NCES, 1, 2003-2313.

Otten, S., \& De Araujo, Z. (2015). Viral criticisms of Common Core mathematics. 21, 217-220.

Passmore, C., \& Stewart, J. (2002). A modeling approach to teaching evolutionary biology in high schools. Journal of Research in Science Teaching, 39(3), 185-204. doi:10.1002/tea.10020

Quarteroni, A. (2009). Mathematical models in science and engineering. Notices of the American Mathematical Society, 56, 10-19.

Robeva, R., \& Laubenbacher, R. (2009). Mathematical biology education: Beyond calculus. Science, 325(5940), 542-543. Retrieved from http://science.sciencemag.org/content/325/5940/542

Roberts, S. (2011). Biomath in the schools. Vol. 76 of DIMACS series in discrete mathematics and theoretical computer science. Providence, RI: American Mathematical Society.

Ross, S. M., Morrison, G. R., \& Lowther, D. L. (2010). Educational technology research past and present: Balancing rigor and relevance to impact school learning. Contemporary Educational Technology, 1(1), 17-35.

Sadler, T. D., Romine, W. L., Stuart, P. E., \& Merle-Johnson, D. (2013). Game-based curricula in biology classes: differential effects among varying academic levels. Journal of Research in Science Teaching, 50(4), 479-499. doi:10.1002/tea.21085

Schneider, M. V., Walter, P., Blatter, M.-C., Watson, J., Brazas, M. D., Rother, K., ... Brooksbank, C. (2012). Bioinformatics Training Network (BTN): A community resource for bioinformatics trainers. Briefings in Biomathematics, 13, 383-389.

Schroeder, C. M., Scott, T. P., Tolson, H., Huang, T.-Y., \& Lee, Y.-H. (2007). A meta-analysis of national research: Effects of teaching strategies on student achievement in science in the United States. Journal of Research in Science Teaching, 44(10), 1436-1460. doi:10.1002/tea.20212

Schultheis, E. H., \& Kjelvik, M. K. (2015). Data nuggets: Bringing real data into the classroom to unearth students' quantitative \& inquiry skills. The American Biology Teacher, 1, 19-29.

Shields, P. M., Esch, C., Lash, A., Padilla, C., Woodworth, K., Laguarda, K. G., \& Winter, N. (2004). Evaluation of Title I Accountability Systems and School Improvement Efforts (TASSIE): first-year findings. Technical Report. P.O. Box 1398, Jessup, MD 20794-1398. Department of Education.

Small, C. J., \& Newtoff, K. N. (2013). Integrating quantitative skills in introductory ecology: Investigations of wild bird feeding preferences. The American Biology Teacher, 75(4), 269-273. Retrieved from http://www.jstor.org/stable/10.1525/abt.2013.75.4.8 
Soderberg, P., \& Price, F. (2003). An examination of problem-based teaching and learning in population genetics and evolution using EVOLVE, a computer simulation. International Journal of Science Education, 25(1), 35-55. doi:10.1080/09500690110095285

Sorgo, A. (2010). Connecting biology and mathematics: first prepare the teachers. CBE Life Sciences Education, 9(3), 196-200.

Speth, E. B., Momsen, J. L., Moyerbrailean, G. A., Ebert-May, D., Long, T. M., Wyse, S., \& Linton, D. (2010). 1, 2, 3, 4: Infusing quantitative literacy into introductory biology. CBE Life Sciences Education, 9(3), 323-332.

Stefan, M. I., Gutlerner, J. L., Born, R. T., \& Springer, M. (2015). The quantitative methods boot camp: Teaching quantitative thinking and computing skills to graduate students in the life sciences. PLOS Computational Biology, 11(4), 1-12. doi:10.1371/journal.pcbi.1004208

Taradi, S. K., Taradi, M., Radic, K., \& Pokrajac, N. (2005). Blending problem-based learning with Web technology positively impacts student learning outcomes in acid-base physiology. Advanced Physiology Education, 29(1), 35-39.

Taylor, D. L., Campbell, A. M., \& Heyer, L. J. (2013). Illuminating the black box of genome sequence assembly: A free online tool to introduce students to bioinformatics. American Biology Teacher, 75(8), 572-577. Retrieved from https://www.learntechlib.org/p/154710

The College Board. (2015). AP Biology: Course and exam description. Technical Report. New York, NY: The College Board. Retrieved from https://secure-media.collegeboard.org/digitalServices/ pdf/ap/ap-biology-course-and-exam-description.pdf

Thompson, K. V., Cooke, T. J., Fagan, W. F., Gulick, D., Levy, D., Nelson, K. C., ... Presson, J. (2013). Infusing quantitative approaches throughout the biological sciences curriculum. International Journal of Mathematical Education in Science and Technology, 44(6), 817-833. doi:10.1080/0020739X.2013.812754

Thompson, K. V., Nelson, K. C., Marbach-Ad, G., Keller, M., \& Fagan, W. F. (2010). Online interactive teaching modules enhance quantitative proficiency for introductory biology students. CBE Life Sciences Education, 9(3), 277-283.

University of Phoenix. (2014). University of Phoenix: $81 \%$ of $K-12$ teachers see some benefits of common core curriculum. Jacksonville, FL: Entertainment Close-up.

Usher, D. C., Driscoll, T. A., Dhurjati, P., Pelesko, J. A., Rossi, L. F., Schleiniger, G., ... White, H. B. (2010). A transformative model for undergraduate quantitative biology education. CBE Life Sciences Education, 9(3), 181-188.

Waight, N., \& Abd-El-Khalick, F. (2011). From scientific practice to high school science classrooms: Transfer of scientific technologies and realizations of authentic inquiry. Journal of Research in Science Teaching, 48(1), 37-70. doi:10.1002/tea.20393

Waldrop, L. D., Adolph, S. C., Diniz Behn, C. G., Braley, E., Drew, J. A., Full, R. J., ... Miller, L. A. (2015). Using active learning to teach concepts and methods in quantitative biology. Integrative and Comparative Biology, 55(5), 933-948.

Waldrop, M. M. (2001). College student meets electron man: Initial panic turns to insight as students embrace online learning. HHMI Bulletin, 11(4), 22-25.

Welner, K. G. (2014). The lost opportunity of the common core state standards. Phi Delta Kappan, 95(7), 39-40. doi:10.1177/003172171409500709

Wightman, B., \& Hark, A. T. (2012). Integration of bioinformatics into an undergraduate biology curriculum and the impact on development of mathematical skills. Biochemistry and Molecular Biology Education, 40(5), 310-319. doi:10.1002/bmb.20637

Williams, M., \& Linn, M. C. (2002). WISE inquiry in fifth grade biology. Research in Science Education, 32(4), 415-436. doi:10.1023/A:1022452719316

Willingale-Theune, J., Manaia, A., Gebhardt, P., De Lorenzi, R., \& Haury, M. (2009). Science education. Introducing modern science into schools. Science, 325(5944), 1077-1078.

Wood, L., \& Gebhardt, P. (2013). Bioinformatics goes to school - new avenues for teaching contemporary biology. PLOS Computational Biology, 9(6), 1-6. doi:10.1371/journal.pcbi.1003089

Yigal, R., Ferrara, S., \& Mosharraf, M. (2015). Handbook of research on technology tools for real-world skill development. Vol. 1 Advances in higher education and professional development. Hershey, PA: IGI Global. 